\title{
Bcl-2-Like Protein 11
}

National Cancer Institute

\section{Source}

National Cancer Institute. BCl-2-Like Protein 11. NCI Thesaurus. Code C21195.

Bcl-2-like protein 11 (198 aa, $\sim 22 \mathrm{kDa}$ ) is encoded by the human BCL2L11 gene. This protein is involved in the induction of apoptosis. 